\title{
Drug refractory faciobrachial dystonic seizures successfully treated with multiple apheresis
}

\author{
Madhu S Jasti*1 ${ }^{*}$ Sandipan Pati ${ }^{2}$, Vinusha Yarlagadda ${ }^{3}$ \\ ${ }^{1}$ Crozer Chester Medical Center, Chester, USA \\ ${ }^{2}$ University of Alabama, Birmingham, USA \\ ${ }^{3}$ Alluri Sitarama Raju Institute of Medical Sciences, India
}

Received: May 19, 2016

DOI: $10.5430 /$ crim.v3n3p69
Accepted: June 20, $2016 \quad$ Online Published: July 10, 2016

URL: http://dx.doi.org/10.5430/crim.v3n3p69

\begin{abstract}
Faciobrachial dystonic epileptic seizures usually precede the cognitive impairment associated with non-paraneoplastic limbic encephalitis secondary to voltage gated potassium channel complex (VGKC) antibodies, specifically to leucine-rich glioma inactivated 1 (LGI1) antibodies. Testing for VGKC-complex/LGI1 antibodies should be initiated with the recognition of faciobrachial dystonic seizures. This seizure subtype is refractory to treatment with the anti-epileptic drugs, but has been shown to be immunotherapy responsive. Early initiation of immunotherapy has been shown to fasten the time to recovery and also in minimizing the cognitive impairment.
\end{abstract}

Key Words: Faciobrachial dystonic seizures, Voltage gated potassium channel complex antibodies, Non paraneoplactic limbic encephalitis, Immunotherapy

\section{INTRODUCTION}

Epilepsy is a central nervous system disorder involving recurrent unprovoked seizures. There are numerous causes of epilepsy and one of those includes an autoimmune causation. Although the exact prevalence of autoimmune epilepsy is not clearly known, autoimmune disorders have long been recognized as potential causes of seizures. Faciobrachial dystonic epileptic seizures fall into this realm of autoimmune epilepsy disorders.

Antibodies targeted against voltage-gated potassium channel complex antibodies, particularly against leucine-rich glioma inactivated 1 component of the channel complex, are associated with limbic encephalitis that present with seizures and cognitive impairment. Faciobrachial dystonic seizures are the seizure subtype in the encephalitis caused by these antibodies. ${ }^{[1]}$ It has been shown in various studies that faciobrachial dystonic seizures usually precede the cognitive impairment and so the clinical diagnosis of this subtype of seizures should prompt the testing for voltage gated potassium channel complex antibodies. The existing clinical data suggests that faciobrachial dystonic seizures are less likely to be associated with an underlying tumor; nonetheless, an occult malignancy should still be excluded.

Faciobrachial dystonic seizures are known to be very resistant to treatment with anti-epileptic drugs. Not only the drug therapy is ineffective, it is also associated with a high risk of adverse reactions. Some of the existing clinical data prove that this seizure subtype responds very well to treatment immunotherapy. ${ }^{[2]}$ Immunotherapy is associated with very good control of seizures, fastens the time to recovery and

*Correspondence: Madhu S Jasti; Email: madhujasti.9@gmail.com; Address: Crozer Chester Medical Center, Chester, PA 19013, USA. 
minimizes the development of cognitive impairment. Due to the fact that the severity of the illness and the long term cognitive disability can be curtailed with the initiation of early immunotherapy, early recognition of the faciobrachial dystonic seizures and prompt workup plays a pivotal role in the management of this syndrome. ${ }^{[3,4]}$

We present a case of non-paraneoplastic, voltage gated potassium channel complex (VGKC)-complex/leucine-rich glioma inactivated 1 (LGI1) antibody positive faciobrachial dystonic seizures, in which the seizures were resistant to treatment with antiepileptic medications, but responded well to treatment with immunotherapy.

\section{CASe PResentation}

Patient is a 79-year-old Caucasian male who presented to the emergency department (ED) after a fall. He attributed the fall to intermittent involuntary rhythmic movements in his body lasting few seconds that developed 3 weeks prior to presentation. These started initially in the left upper extremity, progressed to involve the left lower and right upper extremities and dramatically increased in frequency from once every few days to several per hour. Two months prior to the episodes, patient admitted to killing a raccoon that exhibited abnormal behavior. He sent the animal's brain for autopsy to state health department, which claimed there was not enough brain matter to conclude significant pathology. Patient has hypertension, type-2 Diabetes Mellitus, hyperlipidemia, polymyalgia rheumatica, and 25-year smoking history. On physical exam he was noted to have mild weakness of proximal muscles of left upper extremity, with movement limited by pain in left shoulder joint. Muscle bulk and tone were normal. No fasciculations was noted. Gait was not examined as patient continued to have involuntary movements of his extremities. During the episodes, he had a brief dystonic flexor posture of his left arm and leg, following by rhythmic clonic movement's involving left side of face, and left laterocollis. These lasted for two seconds only. He retained full awareness and recalled the semiology of his episodes accurately. Patient could not identify any triggers. Electrolyte and blood count panels revealed a low serum magnesium level $(1.6 \mathrm{mg} / \mathrm{dl}$, normal range $1.7-2.5$ $\mathrm{mg} / \mathrm{dl}$ ), and mild anemia (Hematocrit 36\%).

In the ED, patient received human rabies immune globulin (HRIG), and the first set of rabies vaccine, although the patient was not bit by or exposed to the raccoon's body fluids. Patient was then admitted to general medical service. 3-Tesla Magnetic resonance images of brain and cervical spinal cord were acquired with and without intravenous gadolinium contrast. MRI Brain showed a T2-weighted hypo intense signal involving the bilateral putamen and red nuclei, and subtle
T2-hyperintensity lateral to both putamen and medial to external capsule. The significance of these findings was not clear. MRI Cervical-spine demonstrated moderate multilevel degenerative changes without abnormal spinal cord signal changes. After the MRI, continuous video electroencephalography (cvEEG) monitoring was started, with several episodes captured. Most episodes had muscle artifact seen on cvEEG, however some had sharply-contoured waveforms over midline and right frontocentral regions. These were classified as faciobrachial focal dystonic seizures, and treatment with $750 \mathrm{mg}$ BID of levetiracetam was initiated.

Cerebrospinal fluid (CSF) analysis showed glucose $96 \mathrm{mg} / \mathrm{dl}$ (serum glucose $170 \mathrm{mg} / \mathrm{dl}$ ), protein $61 \mathrm{mg} / \mathrm{dl}$, white count of $5 / \mathrm{mm}^{3}$, erythrocyte count of $750 / \mathrm{mm}^{3}$, normal CSF Immunoglobulin-G index and synthesis rate, and no oligoclonal bands. A serum paraneoplastic panel was also sent. CT scan of chest, abdomen and pelvis was acquired with and without oral and intravenous contrast to evaluate for possible neoplastic lesions. Thickening of distal esophagus at the gastro-esophageal junction was seen, but otherwise was negative for any malignancy. Scrotal ultrasonography was normal. Levetiracetam was subsequently increased in increments to 2,000 mg BID along with starting clonazepam. Carbamazepine was added to anticonvulsant regimen, which was then switched to oxcarbazepine due to causing horizontal diplopia. Intravenous immunoglobulin infusion was started at a dose of $0.4 \mathrm{gm} / \mathrm{kg} /$ day for five days. Rabies vaccine treatment was not completed as after consultation with infectious disease service and centers for disease control, it was felt that the presentation is not typical for rabies and further workup is not warranted. As patient's symptoms improved, he was discharged to a skilled nursing facility but was re-admitted 2 days later due to worsening movements. The paraneoplastic panel had also returned positive for voltage-gated potassium channel antibody, with titer elevated at $0.29 \mathrm{nmol} / \mathrm{L}$, and leucine-rich Glioma-Activated Protein 1 Antibody (LGI1) with a titer of 1:80. Serum protein electrophoresis revealed elevated gamma fraction at $2 \mathrm{mg} / \mathrm{dl}$ (normal $=0.62-1.51 \mathrm{mg} / \mathrm{dl})$, with one free kappa light chain detected in urine but none in serum. Esophagogastroscopy was pursued and biopsy of the previously seen esophageal lesion showed changes suggestive of an ulcer, and biopsy of the stomach lesion showed chronic gastritis without metaplasia, dysplasia or malignancy. Patient was started on $250 \mathrm{mg}$ BID of intravenous methylprednisolone for five days, and plasmapharesis for a total of five sessions with a very good response to the treatment. Clonazepam and oxcarbazepine were discontinued secondary to hyponatremia, and phenytoin and valproic acid were started. A repeat brain MRI was unchanged. Due to significant improvement in symptoms 
after plasmapharesis, patient was discharged back to SNF with plan for repeat plasmapharesis in 6-8 weeks.

\section{Discussion}

Limbic encephalitis is a neurological syndrome characterized by sub-acute development of episodic memory impairment, cognitive changes, seizures, sleep disturbance and hallucinations. MRI imaging in this syndrome frequently reveals signal changes in the medial temporal lobes, amygdala or bilateral hippocampus. The onset of symptoms is mostly subacute, typically developing over few weeks or months. As the initial presenting symptoms may be subtle, early detection of this clinical condition is difficult. Although it is difficult to recognize early, detecting it early remains very crucial, as early diagnosis and prompt initiation of treatment improves the clinical outcome. ${ }^{[5]}$ The vast existing literature shows that limbic encephalitis is paraneoplastic in origin and numerous cases have been reported with specific autoantibodies. These antibodies may be classified into two categories with some targeting the intracellular proteins and others targeting the extracellular components.

Few examples of the antibodies that target the intracellular proteins include anti $\mathrm{Hu}$ antibodies in patients with lung cancer ${ }^{[6,7]}$ and antiMa2 antibodies in patients with testicular tumours. ${ }^{[8]}$ Treatment strategies like immunotherapy usually do not work in these patients as the antibody targets are intracellular proteins. The clinical course is usually monophasic and relentlessly progressive with a guarded prognosis and treatment is directed at the underlying malignancy. ${ }^{\left[{ }^{9,10]}\right.}$ Most of the time, the prognosis of paraneoplastic limbic encephalitis is poor with only minimal improvement even after the treatment of the primary tumor.

In contrast to the autoimmune encephalitis with intracellular targets, the other distinct entity of autoimmune encephalitis is in which the antibodies are targeted at the neuronal extracellular surface components. ${ }^{[1-13]}$ A few examples of the identified targets include components of the voltage gated potassium channel complex and N-methyl-D-aspartate receptor. ${ }^{[14,15]}$ The limbic encephalitis associated with extracellular/neuronal surface antibodies often have a relapsing course with an overall better prognosis. These are less commonly paraneoplastic ${ }^{[16]}$ with a better treatment response to immunotherapies, although early initiation of the treatment holds the key for a better prognosis.

\subsection{VGKC-LGI1 antibodies}

Voltage gated potassium channel complex on cell surface membranes is a key protein determining neuronal excitability. Antibodies against this target are very well known to be associated with disorders of the peripheral nervous system such as acquired neuromyotonia, cramp-fasciculation syndrome $^{[17]}$ and Morvan's syndrome (neuromyotonia, dysautonomia, cognitive changes and sleep impairment). ${ }^{[18-21]}$

Subsequently, antibodies to voltage gated potassium channel complex were also identified in patients with limbic encephalitis in the context of an acute to sub-acute amnestic encephalopathy, seizures, sleep disturbance, hyponatremia, and imaging abnormalities on MRI. ${ }^{[22]}$ Typically, voltage gated potassium channel complex associated antibody mediated limbic encephalitis is non-paraneoplastic. ${ }^{[23-26]}$ A study found that antibodies from patients diagnosed with voltage gated potassium channel complex associated limbic encephalitis were bound specifically to LGI1 component of the complex and are implicated with adult-onset brief and frequent motor events consisting of unilateral upper or lower limb jerking and ipsilateral facial grimacing, termed as faciobrachial dystonic seizures. ${ }^{[27,28]}$ This presentation most often precedes the development of more classical limbic encephalitis and is an important differential in patients with rapidly progressive dementia.

\subsection{The encephalitis associated with VGKC-LGI1 anti- bodies}

The encephalopathy secondary to voltage gated potassium channel complex antibodies is a rare form of autoimmune, non-paraneoplastic and potentially treatable encephalitis. This condition mostly affects middle age or elderly patients with a male to female predominance in the ratio of 2:1. Clinical manifestations include frequent myoclonic jerks in the face, arm, or leg (faciobrachial dystonic seizures). ${ }^{[29]}$ The clinical presentation may also involve also prominent shortterm memory deficits, confusion, sleep disturbances, and psychiatric changes including depression and hallucinations. ${ }^{[30]}$ About $60 \%$ of the patients have concomitant hyponatremia. Most of the labs including the infectious and metabolic studies will usually be normal. Serological testing is available to confirm the diagnosis. Most of the time, CSF studies will be normal with serum strongly positive voltage gated potassium channel complex antibodies. MRI imaging may be associated with medial temporal lobe or bilateral basal ganglia signal changes. Electroencephalography usually shows nonspecific changes with generalized slowing. It may show focal sharp waves especially in the temporal regions in some cases. Korsakoff's syndrome and Herpes zoster are the two major differential diagnosis, but obviously will have to rule out other infectious, metabolic, and toxic etiologies. The probability of voltage gated potassium channel complex associated encephalitis should be considered high on the differential diagnosis list in patients presenting with sub-acute onset of cognitive impairment, seizures and MRI imaging abnormali- 
ties in the limbic region as the prompt recognition and early treatment of this syndrome impacts the clinical outcome.

\subsection{Treatment}

A very small proportion of patients can have spontaneous remission without therapy. Most of the time faciobrachial dystonic seizures are very resistant to treatment with antiepileptic drugs. Despite being ineffective for this particular clinical condition, the antiepileptic drug therapy is also associated with high risk of adverse reactions. Faciobrachial dystonic seizures have been shown to be responsive to treatment with immunotherapy. Immunotherapy is associated with very good control of seizures, fastens the time to recovery and minimizes the development of cognitive impairment. ${ }^{[31]}$

Treatment is in the similar lines as of other autoimmune non-paraneoplastic limbic encephalitis. ${ }^{[32]}$ First line therapy is usually in the form of pulsed steroids followed by high dose oral prednisone, and IVIg and/or plasmapheresis. ${ }^{[33]}$ Failure to respond within a week should lead to consideration of five exchanges with plasmapheresis. If refractory to these treatments, then immunosuppression with drugs like cyclophosphamide or rituximab should be considered. ${ }^{[34]}$ Immunosuppression could help not only by reducing serum antibody levels, but also by reducing inflammation and permeability of the blood brain barrier. ${ }^{[35,36]}$ The immunosuppressant therapy may be discontinued after attainment of a steady state of clinical improvement. Objectively, the response to treatment can be assessed by serially measuring voltage gated potassium channel complex antibody levels and also with serial EEGs and MRI.

\subsection{Conclusion}

Faciobrachial dystonic seizures precede voltage gated potassium channel complex/leucine-rich glioma inactivated 1 antibody limbic encephalitis. Because early treatment of the disease limits the duration as well as the severity of the illness and the degree of cognitive disability, prompt recognition of these seizures offers a window of opportunity for early treatment with immunotherapy and the likely prevention of a permanent disability.

\section{CONFLicts OF InTEREST Disclosure}

The authors have declared no conflicts of interest.

\section{REFERENCES}

[1] Irani SR, Michell AW, Lang B, et al. Faciobrachial dystonic seizures precede Lgil antibody limbic encephalitis. Ann Neurol. 2011; 69: 892-900. PMid:21416487 http://dx.doi.org/10.1002/ana. 2 2307

[2] Vincent A, Buckley C, Schott JM, et al. Potassium channel antibody associated encephalopathy: a potentially immunotherapyresponsive form of limbic encephalitis. Brain. 2004; 127: 701-712. PMid:14960497 http://dx.doi.org/10.1093/brain/awh077

[3] Graus F, Saiz A, Lai M, et al. Neuronal surface antigen antibodies in limbic encephalitis: clinical-immunologic associations. Neurology. 2008; 71: 930-936. PMid:18794496 http://dx.doi.org/10.12 12/01.wnl.0000325917.48466.55

[4] Bien CG, Urbach H, Schramm J, et al. Limbic encephalitis as a precipitating event in adult-onset temporal lobe epilepsy. Neurology. 2007; 69: 1236-1244. PMid:17875912 http://dx.doi.org/10. 1212/01.wnl.0000276946.08412.ef

[5] Anderson NE, Barber PA. Limbic encephalitis: a review. J Clin Neurosci. 2008; 15: 961-971. PMid:18411052 http://dx.doi .org/1 $0.1016 /$ j. jocn. 2007.12.003

[6] Alamowitch S, Graus F, Uchuya M, et al. Brain. 1997; 120(Pt 6): $923-$ 8. PMid:9217677 http://dx.doi.org/10.1093/brain/120.6 .923

[7] Graus F, Keime-Guibert F, Rene R, et al. Anti-Hu-associated paraneoplastic encephalomyelitis: analysis of 200 patients. Brain. 2001; 124: $1138 \mathrm{e} 48$.

[8] Voltz R, Gultekin SH, Rosenfeld MR, et al. A serologic marker of paraneoplastic limbic and brain-stem encephalitis in patients with testicular cancer. N Engl J Med. 1999; 340: 1788-95. PMid:10362822 http://dx.doi.org/10.1056/NEJM199906103402303
[9] Lancaster E, Martinez-Hernandez E, Dalmau J. Encephalitis and antibodies to synaptic and neuronal cell surface proteins. Neurology. 2011; 77: 179-89. PMid:21747075 http://dx.doi.org/10.12 12/WNL. Ob013e318224afde

[10] Bien CG, Vincent A, Barnett MH, et al. Immunopathology of autoantibody associated encephalitides: clues for pathogenesis. Brain. 2012; 135: 1622-38. PMid:22539258 http://dx.doi.org/10.10 93/brain/aws082

[11] Graus F, Saiz A, Dalmau J. Antibodies and neuronal autoimmune disorders of the CNS. J Neurol. 2010; 257: 509-17. PMid:20035430 http://dx.doi.org/10.1007/s00415-009-5431-9

[12] Ances BM, Vitaliani R, Taylor RA, et al. Treatment-responsive limbic encephalitis identified by neuropil antibodies: MRI and PET correlates. Brain. 2005; 128: 1764-77. PMid:15888538 http: //dx.doi.org/10.1093/brain/awh526

[13] Samarasekera SR, Vincent A, Welch JL, et al. Course and outcome of acute limbic encephalitis with negative voltage-gated potassium channel antibodies. J Neurol Neurosurg Psychiatry. 2007; 78: 391-4. PMid:17098840 http://dx.doi.org/10.1136/jnnp. 20 06.093096

[14] Hughes EG, Peng X, Gleichman AJ, et al. Cellular and synaptic mechanisms of anti-NMDA receptor encephalitis. J Neurosci. 2010; 30: 5866-75. PMid:20427647 http://dx.doi.org/10.1523/J NEUROSCI . 0167-10.2010

[15] Lancaster E, Lai M, Peng X, et al. Antibodies to the GABA(B) receptor in limbic encephalitis with seizures: case series and characterisation of the antigen. Lancet Neurol. 2010; 9: 67-76. http: //dx.doi.org/10.1016/S1474-4422(09)70324-2

[16] Buckley C, Oger J, Clover L, et al. Potassium channel antibodies in two patients with reversible limbic encephalitis. Ann Neurol. 2001; 
50: 73-8. PMid:11456313 http://dx.doi.org/10.1002/ana.1 097

[17] Vernino S, Lennon VA. Ion channel and striational antibodies define a continuum of autoimmune neuromuscular hyperexcitability. Muscle Nerve. 2002; 26: 702-7. PMid:12402293 http://dx.doi .org/10. 1002 /mus. 10266

[18] Tan KM, Lennon VA, Klein CJ, et al. Clinical spectrum of voltagegated potassium channel autoimmunity. Neurology. 2008; 70: 188390. PMid:18474843 http://dx.doi.org/10.1212/01.wnl.00 00312275.04260.a0

[19] Cornelius JR, Pittock SJ, McKeon A, et al. Sleep manifestations of voltage-gated potassium channel complex autoimmunity. Arch Neurol. 2011; 68: 733-8. PMid:21670396 http://dx.doi.org/1 0.1001 /archneurol.2011.106

[20] Barber PA, Anderson NE, Vincent A. Morvan's syndrome associated with voltage-gated $\mathrm{K}+$ channel antibodies. Neurology. 2000; 54 : 771-2. PMid:10680828 http://dx.doi.org/10.1212/wNL. 54 . 3.771

[21] Liguori R, Vincent A, Clover L, et al. Morvan's syndrome: peripheral and central nervous system and cardiac involvement with antibodies to voltage-gated potassium channels. Brain. 2001; 124: 2417-26. PMid:11701596 http://dx.doi.org/10.1093/brain/124.12. 2417

[22] Pozo-Rosich P, Clover L, Saiz A, et al. Voltage-gated potassium channel antibodies in limbic encephalitis. Ann Neurol. 2003; 54: 530-3. PMid:14520669 http://dx.doi.org/10.1002/ana. 10713

[23] Jarius S, Hoffmann L, Clover L, et al. CSF findings in patients with voltage gated potassium channel antibody associated limbic encephalitis. J Neurol Sci. 2008; 268: 74-7. PMid:18068189 http://dx.doi.org/10.1016/j.jns.2007.11.004

[24] Bien CG. Limbic encephalitis: extension of the diagnostic armamentarium. J Neurol Neurosurg Psychiatry. 2007; 78: 3323. PMid:17018560 http://dx.doi.org/10.1136/jnnp. 2006 .106757

[25] Ohshita T, Kawakami H, Maruyama H, et al. Voltage-gated potassium channel antibodies associated limbic encephalitis in a patient with invasive thymoma. J Neurol Sci. 2006; 250: 167-9. PMid:17028029 http://dx.doi.org/10.1016/j.jns.2006.08.003

[26] Jarius S, Hoffmann LA, Stich O, et al. Relative frequency of VGKC and 'classical' paraneoplastic antibodies in patients with limbic encephalitis. J Neurol. 2008; 255: 1100-1. PMid:18574619 http://dx.doi.org/10.1007/s00415-008-0845-3
[27] Lai M, Huijbers MG, Lancaster E, et al. Investigation of LGI1 as the antigen in limbic encephalitis previously attributed to potassium. Lancet Neurol. 2010; 9(8): 776-85. http://dx.doi.org/10.10 16/S1474-4422(10) 70137-X

[28] Striano P. Faciobrachial dystonic attacks: seizures or movement disorder? Ann Neurol. 2011; 70: 179-80. PMid:21786308 http: //dx.doi.org/10.1002/ana.22470

[29] Andrade DM, Tai P, Dalmau J, et al. Tonic seizures:a diagnostic clue of anti-LGI1 encephalitis? Neurology. 2011; 76: 13551357. PMid:21482953 http://dx.doi.org/10.1212/WNL.0b0 13 e3182152808

[30] Irani, SR, Alexander S, Waters P, et al. Antibodies to Kv1 potassium channel-complex proteins leucinerich,glioma inactivated 1 protein and contactin-associated protein-2 in limbic encephalitis, Morvan's syndrome and acquired neuromyotonia. Brain. 2010; 133: 2734-2748 PMid:20663977 http://dx.doi.org/10.1093/brain/awq213

[31] Irani SR, Stagg CJ, Schott JM, et al. Faciobrachial dystonic seizures: the influence ofimmunotherapy on seizure control and prevention of cognitive impairment in a broadening phenotype. Brain. 2013; 136 3151-3162. PMid:24014519 http://dx.doi .org/10.1093/bra in/awt212

[32] Dalmau J, Gleichman AJ, Hughes EG, et al. Anti-NMDA-receptor encephalitis: case series and analysis of the effects of antibodies. Lancet Neurol. 2008; 7: 1091-8. http://dx.doi.org/10.1016 /S1474-4422 (08) 70224-2

[33] Irani SR, Vincent A. NMDA receptor antibody encephalitis. Curr Neurol Neurosci Rep. 2011; 11: 298-304. PMid:21331529 http: //dx.doi.org/10.1007/s11910-011-0186-y

[34] Ishiura H, Matsuda S, Higashihara M, et al. Response of anti-NMDA receptor encephalitis without tumor to immunotherapy including rituximab. Neurology. 2008; 71: 1921-3. PMid:19047564 http: //dx.doi.org/10.1212/01.wnl.0000336648.43562.59

[35] Kashiwamura Y, Sano Y, Abe M, et al. Hydrocortisone enhances the function of the blood-nerve barrier through the up-regulation of claudin-5. Neurochem Res. 2011; 36: 849-55. PMid:21293925 http://dx.doi.org/10.1007/s11064-011-0413-6

[36] Gaillard PJ, van Der Meide PH, de Boer AG, et al. Glucocorticoid and type 1 interferon interactions at the blood-brain barrier: relevance for drug therapies for multiple sclerosis. Neuroreport. 2001; 12 : 2189-93. PMid:11447332 http://dx.doi.org/10.1097/00001 756-200107200-00029 